\title{
Water Flow Through the Pits in Eucalyptus urophylla Wood
}

\author{
Thiago Campos Monteiro ${ }^{1}$ (1) 0000-0002-3819-7035
}

José Tarcísio Lima

\begin{abstract}
This research aimed to evaluate the relationship between Vessel-Ray Pits (VRP) and Intervessel Pits (IVP) and water flows in the different axes of Eucalyptus urophylla wood. Samples of E. urophylla wood were used to correlate the VRP and IVP dimensions with free, adsorbed and total water flow rates. Correlations were conducted for the three axes of the wood. Results indicated that overall, it could be observed that the greater VRP and IVP in the axial axis of wood increased free water and absorbed water flows. On the one hand, the greater VRP in the radial and tangential directions reduced the free water flow and increased the absorbed water flow. On the other hand, the greater IVP in the radial and tangential directions of the wood accelerated the free water outlet and reduced the absorbed water flow. The VRP and IVP of E. urophylla wood influenced water flow according to its physical state and wood axis.
\end{abstract}

Keywords: free water, adsorbed water, drying, Vessel-Ray Pit (VRP), Intervessel Pit (IVP).

\section{Introduction}

Water flow in wood has been already researched, for at least, a century. According to the literature review presented by Engelund et al. (2013) on this topic, research on the water-wood interactions has been mainly performed with coniferous species. In the last years, water-wood interaction in hardwoods has also been studied, mainly in Brazil. In this scenario, family Myrtaceae is highlighted for studies on the genus Eucalyptus (Silva et al., 2010; Zanuncio et al., 2013; Monteiro et al., 2017, 2018; Nascimento et al., 2019; Zen et al., 2019).

It is well-known that fibers, vessel elements, and radial and axial parenchyma cells make the Eucalyptus urophylla wood porous. The passage of fluids through these structures is complex, seeing that it is performed with water in both liquid and gaseous phases (Siau, 1971). Water flow in the stem of hardwoods occurs mainly through vessels and pit pairs (Siau, 1971; Engelund et al., 2013). However, these anatomical structures can be obstructed by tyloses, and then interfere with water flow, especially at the heartwood (De Micco et al., 2016; Helmling et al., 2018; Brito et al., 2019). All this complexity of wood-water interactions increases, when analyzed in the different axes of wood, may occur due to several permeability techniques that can flow only in the axial axis (Silva et al., 2010; Baraúna et al., 2014; Zanuncio et al., 2016; Rezende et al.,
2018) or in the three directions by using techniques of safranin solution flow in the wood (Ahmed \& Chun, 2011). Beyond the axes, few studies have addressed the free water and adsorbed water flows during drying in hardwoods, when being analyzed in detail, mainly for the genus Eucalyptus.

Knowing the effect of Vessel-Ray Pit (VRP) and Intervessel Pit (IVP) of hardwood in water flow is important to optimize the industrialization of this wood, especially as there are few existing reports focused on vessels, rays, and cell wall (Siau, 1971; Baraúna et al., 2014; Zanuncio et al., 2016; Monteiro et al., 2017). A different situation is found for coniferous wood since the importance of bordered pits in water flow has been widely reported in several studies (Kedrov, 2012; Engelund et al., 2013). Therefore, this research aimed to evaluate the relationship between the biometrics of VRP and IVP and well as water flow in the different axes of E. urophylla wood.

\section{Material and methods}

\subsection{Material selection and preparation}

Six trees of an E. urophylla clone were granted by the Brazilian subsidiary Vallourec Florestal Ltda. The plantation, located in the municipality of Paraopeba (in the State of Minas Gerais, in Brazil), had a spacing of $3 \times 3$ meters between the trees.

${ }^{1}$ Universidade Federal do Paraná (UFPR), Curitiba, PR, Brasil

${ }^{2}$ Universidade Federal de Lavras (UFLA), Lavras, MG, Brasil 
The trees were cut at the age of seven. One central lumber of the log from the base of the tree was removed, and two battens on opposite sides were produced.

Cubic test specimens with edges of $30 \mathrm{~mm}$ were produced from each batten in the Wood Machining Laboratory of the Federal University of Lavras (in Portuguese Universidade Federal de Lavras (UFLA)). The cube in the intermediate position of the batten was removed to determine the pit diameter. The other samples were split in half, according to the orientation of the drying axis, with dimensions of $30 \times 30 \times 15 \mathrm{~mm}$. The axis with the smallest dimension was used to evaluate water flow, being evaluated in the axial, radial, and tangential axes. The other corners of the sample were waterproofed to force drying only in the direction evaluated.

\subsection{Water flow evaluation}

The samples were acclimated in an air-conditioned room with a temperature of $20 \pm 2{ }^{\circ} \mathrm{C}$ and relative humidity of $65 \pm 5 \%$. Mass loss of the samples was performed for 75 days until all samples had obtained constant mass. These tests were conducted in the Physical and Mechanical Properties of Wood Laboratory at the UFLA. The mass of the samples was measured in a digital electronic scale with an accuracy of $0.01 \mathrm{~g}$ every 6 hours in the first week, every 12 hours in the second week, and every 24 hours until mass stabilization. After this period, the samples were kiln-dried with a temperature of $103 \pm 2{ }^{\circ} \mathrm{C}$, until they reached constant mass.

After monitoring the sample drying and obtaining drying times and moisture contents, Free Water Flow Rate (FWFR), Adsorbed Water Flow Rate (AWFR), and Total Water Flow Rate (TWFR) were estimated according to a methodology adapted from Monteiro et al. (2018), considering the different axes of the wood.

\subsection{Pit measurement}

The diameters of VRP and IVP were measured in the twelve intermediate specimens of each batten. The measurements were taken in the Electronic Microscopy Laboratory at the UFLA.
Sample preparation and measurements were performed based on Alves \& Roswalka's (2012) method.

\subsection{Analysis of the results}

A database with information on water flow rates and also on values of VRP and IVP was developed for each axis of the wood. Correlations of pit diameters and drying rates were calculated, and regression models were adjusted. The best results were selected based on their coefficient of determination $\left(\mathrm{R}^{2}\right)$.

\section{Results}

Table 1 presents data on the models with their respective coefficients of determination between the VRP and IVP opening diameters as well as the FWFR and AWFR and total drying, up to equilibrium moisture, in the three axes of the wood.

Figure 1 illustrates the directly proportional relationship between the FWFR and AWFR and the VRP diameter in the axial axis of E. urophylla wood.

Figure 2 presents the VRP and IVP in E. urophylla wood.

Figure 3 shows the inverse behavior between the FWFR and AWFR due to the increased VRP in the tangential axis (A) and IVP in the radial axis (B) of E. urophylla wood.

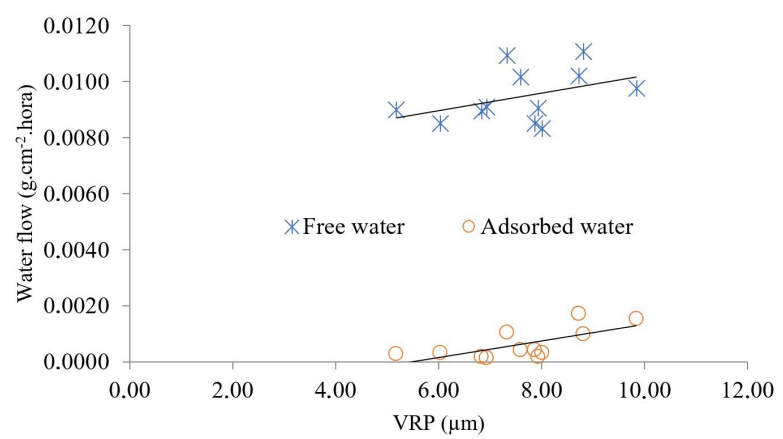

Figure 1. Relationship between the free water and adsorbed water flows, as well as the diameter of Vessel-Ray Pits (VRP) in the axial axis of Eucalyptus urophylla wood.

Table 1. Correlation between water flow in the different axes of Eucalyptus urophylla wood and diameter of Vessel-Ray Pits (VRP) and Intervessel Pits (IVP).

\begin{tabular}{|c|c|c|c|c|}
\hline Wood axes & Vessel-ray pits (VRP) & $\mathbf{R}^{2}$ & Intervessel pits (IVP) & $\mathbf{R}^{2}$ \\
\hline \multirow{3}{*}{ Axial } & $\mathrm{FWFR}=0.0003 \mathrm{VRP}+0.0071$ & 0.17 & $\mathrm{FWFR}=0.0013 \mathrm{IVP}+0.0073$ & 0.52 \\
\hline & AWFR $=0.0003$ VRP -0.0016 & 0.47 & AWFR $=0.0002 \mathrm{IVP}+0.0002$ & 0.03 \\
\hline & $\mathrm{TWFR}=0.0002 \mathrm{VRP}+0.0017$ & 0.11 & TWFR $=-0.0003 \mathrm{IVP}+0.0037$ & 0.02 \\
\hline \multirow{3}{*}{ Radial } & $\mathrm{FWFR}=-0.0003 \mathrm{VRP}+0.008$ & 0.29 & $\mathrm{FWFR}=0.0003 \mathrm{IVP}+0.0052$ & 0.31 \\
\hline & $\mathrm{AWFR}=4 \mathrm{E}-05 \mathrm{VRP}+1 \mathrm{E}-04$ & 0.31 & AWFR $=-0.0001 \mathrm{IVP}+0.0007$ & 0.54 \\
\hline & $\mathrm{TWFR}=4 \mathrm{E}-\mathrm{O} 5 \mathrm{VRP}+0.0013$ & 0.04 & TWFR $=-0.0003 \mathrm{IVP}+0.0022$ & 0.24 \\
\hline \multirow{3}{*}{ Tangential } & FWFR $=-0.0005 \mathrm{VRP}+0.0079$ & 0.55 & $\mathrm{FWFR}=0.0004 \mathrm{IVP}+0.003$ & 0.15 \\
\hline & $\mathrm{AWFR}=4 \mathrm{E}-05 \mathrm{VRP}+2 \mathrm{E}-05$ & 0.36 & AWFR $=-0.0001 \mathrm{IVP}+0.0008$ & 0.33 \\
\hline & TWFR $=-3 \mathrm{E}-06 \mathrm{VRP}+0.0014$ & 0.00 & TWFR $=-0.0003 \mathrm{IVP}+0.0022$ & 0.29 \\
\hline
\end{tabular}

Where: $\mathrm{R}^{2}$ : coefficient of determination; FWFR: Free Water Flow Rate; AWFR: Adsorbed Water Flow Rate; TWFR: Total Water Flow Rate; VRP: diameter of the Vessel-Ray Pits; IVP: diameter of Intervessel Pits. 
A

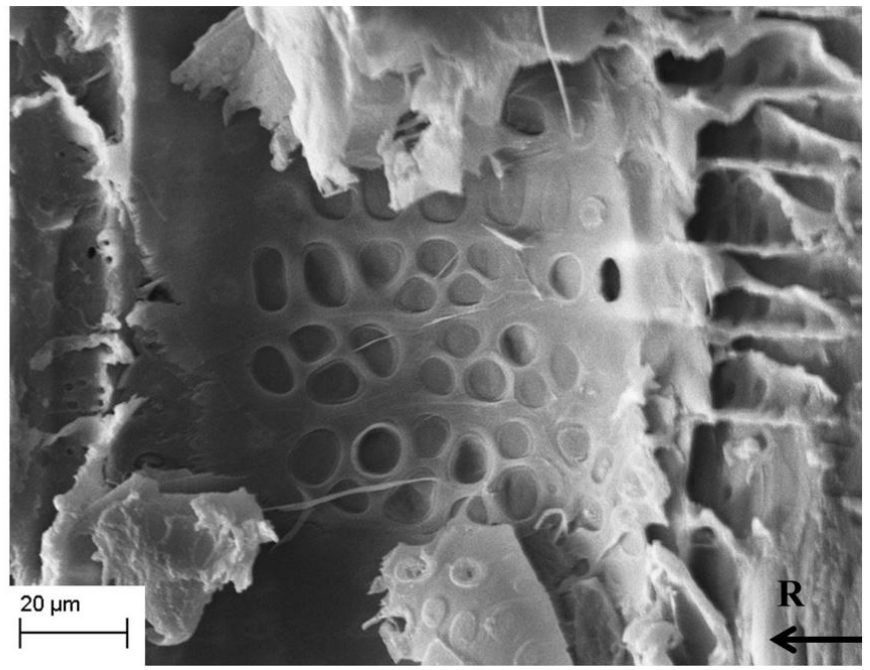

B

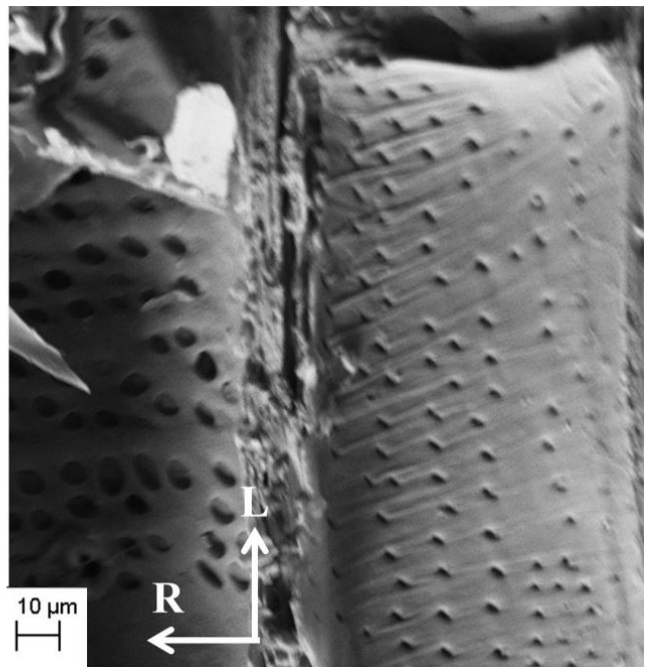

Figure 2. Pits in Eucalyptus urophylla wood. (A) Vessel-ray; (B) Intervessel (R: radial direction; L: longitudinal direction).
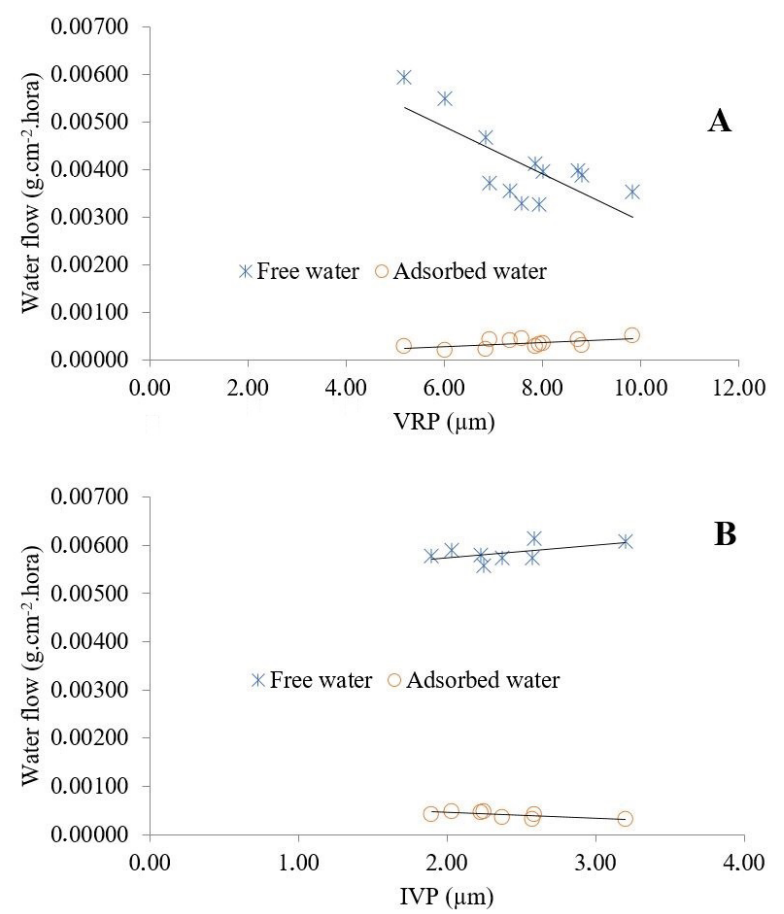

Figure 3. Relationship between the Free Water Flow Rate (FWFR) and Adsorbed Water Flow Rate (AWFR) and the pit diameters in Eucalyptus urophylla wood. (A) Vessel-ray pit (VRP) in the tangential axis; (B) Intervessel pit (IVP) in the radial axis.

\section{Discussion}

The largest VRP and IPV opening facilitated the FWFR in the axial axis of E. urophylla wood (Table 1). Under these circumstances, the same behavior occurred for the AWFR. However, it had a coefficient of determination $\left(\mathrm{R}^{2}\right)$ close to zero for the IVP. These results demonstrated that VRP and IVP positively assisted water flow in the longitudinal direction of the lumber, helping the vessels in this function. The vessel elements are the main structures responsible for carrying water in hardwoods (Siau, 1971; Kedrov, 2012; Engelund et al., 2013), in addition the dimensions and shape of their pits (Jansen et al., 2011; Kedrov, 2012).

Pits may also help to form tyloses and gums inside the vessels (De Micco et al., 2016; Helmling et al., 2018) and consequently to reduce wood permeability, especially at the heartwood (Brito et al., 2019). However, few existing studies on this subject could not differentiate water flow in its different physical states. Thus, the results obtained in this study reinforce the importance of pits in water transporting in both liquid and vaporous states (Figure 1).

The water flow in the radial and tangential axes of the wood presented similar behavior when the effect of VRP and IVP opening on drying was analyzed (Table 1). Greater VRP openings reduced the FWFR in the transverse direction of the wood, reducing the liquid water capillarity as well. Larger openings between the vessel elements and the radial parenchyma (Figure 2A) may contribute to the liquid water flow to be more complex and consequently slower. However, other pit analyses should be conducted for reassurance, for instance on pit structure and frequency (Choat et al., 2008; Kedrov, 2012).

The greater VRP favored the AWFR in the radial and tangential directions, also facilitating the phenomenon of water diffusion. Figure 3A represents the relationship between the FWFR and AWFR and the VRP opening for the tangential axis of the wood, which presented the highest $\mathrm{R}^{2}$ - with a value of 0.55 (Table 1). The opposite behavior between the FWFR and AWFR and the increased pit opening for the radial and tangential axes of the wood resulted in zero correlations, with $\mathrm{R}^{2}$ close to zero, when analyzed for total drying.

The IVP and VRP openings presented the same water flow behavior in the radial and tangential axes (Table 1). However, 
the increased IVP opening in these directions resulted in higher FWFR, facilitating the phenomenon of capillary and the reduction of the AWFR and hindering the phenomenon of water diffusion. Figure 3B reports the relationship between water flow and IVP in the radial axis of the wood. It is worth noting that the IVP of E. urophylla wood is smaller and more frequent when compared to its VRP (Figure 2B). However, it was not possible to evaluate this parameter by testing it in four study samples due to the occurrence of solitary vessels.

The greater IVP opening, possibly allied to its shape and frequency, favored the liquid water flow. A different behavior was observed for the VRP. Kedrov (2012) reported IVP's relevance in water flow and presented numerous pits which tend to get flattened in their contact areas to improve water passage. The author also stated that adjacent walls are thicker in IVP than in other segments of the vascular element, possibly because water penetrates pits under pressure. In addition, as the tree ages and consequently the heartwood increases, tyloses can be formed at the pits and reduce wood permeability (De Micco et al., 2016).

The water vapor diffusion, estimated by the absorbed water flow, was reduced as the IVP opening increased. The increased IVP opening, allied with its shape and frequency, is possibly a cell wall discontinuity, which exposed hydroxyl groups of the wood polymers that attract water molecules, hindering the flow. Hydrogen bonds are formed in sorption areas (Simpson, 1980) along with other polar chemical groups that attract water (Berthold et al., 1996).

\section{Conclusions}

Based on the evaluation of the correlations between the diameters of VRP, IVP, FWFR, AWFR and TWFR in the different axes of $E$. urophylla wood, it was possible to conclude that:

- Greater VRP and IVP in the axial axis of E. urophylla wood overall increased the FWFR and AWFR;

- Radial and tangential axes showed the same behavior for the effect of VRP and IVP diameters on water flow;

- On the one hand, greater VRP in the radial and tangential directions reduced FWFR and increased AWFR. On the other hand, greater IVP in the transverse direction of the wood accelerated the free water outlet and reduced the AWFR;

- The opposite behavior between the FWFR and AWFR and the pit opening resulted in zero correlations in the total drying with these openings.

\section{Acknowledgements}

To the company Vallourec Florestal Ltda for the financial support and also for the team of the Post-Graduation Program in Wood Science and Technology at the UFLA for the technical assistance.

\section{Submission status}

Received: 18 July, 2019

Accepted: 12 Mar., 2020

Associated Editor: João Vicente de Figueiredo Latorraca (ORCID: 0000-0002-5969-5199).

\section{Correspondence to \\ Thiago Campos Monteiro}

Universidade Federal do Paraná (UFPR), Departamento de Engenharia e Tecnologia Florestal, Av. Prefeito Lothário Meissner, 632, Jardim Botânico, CEP: 80210-170, Curitiba, PR, Brasil e-mail: thiago.monteiro@ufpr.br

\section{References}

Ahmed SA, Chun SK. Permeability of Tectona grandis L. as affected by wood structure. Wood Science and Technology 2011; 45(3): 487500. http://dx.doi.org/10.1007/s00226-010-0335-5.

Alves E, Roswalka LC. Técnicas de microscopia aplicadas ao estudo da interações planta-patógeno na pós-colheita. In: Oliveira SMA, Lins SRO, Santos AMG, editors. Avanços tecnológicos na patologia pós-colheita. 1. ed. Recife: Edufrpe; 2012.

Baraúna EEP, Lima JT, Vieira RS, Silva JRM, Monteiro TC. Efeito da estrutura anatômica e química na permeabilidade da madeira de Amapá. Cerne 2014; 20(4): 529-534.

Berthold J, Rinaudo M, Salmeń L. Association of water to polar groups-estimations by an adsorption model for lignocellulosic materials. Colloids and Surfaces A: Physicochemical and Engineering Aspects 1996; 112(2-3): 117-129. http://dx.doi.org/10.1016/09277757(95)03419-6.

Brito AS, Vidaurre GB, Oliveira JTS, Missia da Silva JG, Rodrigues BP, Carneiro ACO. Effect of planting spacing in production and permeability of heartwood and sapwood of Eucalyptus wood. Floresta e Ambiente 2019; 26(spe1): e20180378. http://dx.doi. org/10.1590/2179-8087.037818.

Choat B, Cobb AR, Jansen S. Structure and function of bordered pits: new discoveries and impacts on whole-plant hydraulic function. The New Phytologist 2008; 177(3): 608-625. http://dx.doi. org/10.1111/j.1469-8137.2007.02317.x. PMid:18086228.

De Micco V, Balzano A, Wheeler EA, Baas P. Tyloses and gums: a review of structure, function and occurrence of vessel occlusions. IAWA Journal 2016; 37(2): 186-205. http://dx.doi.org/10.1163/2294193220160130 .

Engelund ET, Thygesen LG, Svensson S, Hill CAS. A critical discussion of the physics of wood-water interactions. Wood Science and Technology 2013; 47(1): 141-161. http://dx.doi.org/10.1007/ s00226-012-0514-7.

Helmling S, Olbrich A, Heinz I, Koch G. Atlas of vessel elements. IAWA Journal 2018; 39(3): 249-352. http://dx.doi.org/10.1163/2294193220180202.

Jansen S, Gortan E, Lens F, Lo Gullo MA, Salleo S, Scholz A et al. Do quantitative vessel and pit characters account for ion-mediated changes in the hydraulic conductance of angiosperm xylem? The New Phytologist 2011; 189(1): 218-228. http://dx.doi.org/10.1111/j.14698137.2010.03448.x. PMid:20840611. 
Kedrov GB. Functioning wood. Wulfenia 2012; 19: 57-95.

Monteiro TC, Lima JT, Hein PRG, Silva JRM, Trugilho PF, Andrade HB. Efeito dos elementos anatômicos da madeira na secagem das toras de Eucalyptus e Corymbia. Scientia Forestalis 2017; 45(115): 493-505. http://dx.doi.org/10.18671/scifor.v45n115.07.

Monteiro TC, Lima JT, Silva JRM, Zanuncio AJV, Baraúna EEP. Water flow evaluation in Eucalyptus and Corymbia short logs. Floram 2018; 25(2): e20170659. http://dx.doi.org/10.1590/21798087.065917.

Nascimento TM, Monteiro TC, Baraúna EEP, Moulin JC, Azevedo AM. Drying influence on the development of cracks in Eucalyptus logs. BioResources 2019; 14(1): 220-233.

Rezende RN, Lima JT, Paula LER, Hein PRG, Silva JRM. Wood permeability in Eucalyptus grandis and Eucalyptus dunnii. Floresta e Ambiente 2018; 25(1): e20150228.

Siau JF. Flow in wood. Syracuse: Syracuse University Press; 1971.
Silva MR, Machado GO, Deiner LJ, Calil C Jr. Permeability measurements of brazilian Eucalyptus. Materials Research 2010; 13(3): 281-286. http://dx.doi.org/10.1590/S1516-14392010000300002.

Simpson W. Sorption theories applied to wood. Wood Fiber 1980; 12: 183-195.

Zanuncio AJV, Carvalho AG, Damásio RAP, Oliveira BS, Carneiro ACO, Colodette JL. Relationship between the anatomy and drying in Eucalyptus grandis $\mathrm{x}$ Eucalyptus urophylla wood. Revista Árvore 2016; 40(4): 723-729. http://dx.doi.org/10.1590/0100-67622016000400016.

Zanuncio AJV, Monteiro TC, Lima JT, Andrade HB, Carvalho AG. Biomass for energy use of Eucalyptus urophylla and Corymbia citriodora logs. BioResources 2013; 8(4): 5159-5168. http://dx.doi. org/10.15376/biores.8.4.5159-5168.

Zen LR, Monteiro TC, Schaeffer WA, Kaminski JM, Klitzke RJ. Secagem ao ar livre da madeira serrada de eucalipto. Journal of Biotechnology and Biodiversity 2019; 7(2): 291-298. http://dx.doi. org/10.20873/jbb.uft.cemaf.v7n2.zen. 